\title{
Editorial
}

\section{Diagnosis Related Groups: quelles perspectives?}

Alors que d'importants progrès ont été réalisés dans les domaines médicaux et sanitaires depuis la Seconde Guerre mondiale, la gestion des hôpitaux a comparativement peu évolué durant cette même période: les modalités de décision sont restées les mêmes, malgré les profonds bouleversements de la structure et de l'activité hospitalières. Depuis une vingtaine d'années, des chercheurs ont développé des méthodes descriptives permettant de saisir, dans toute leur complexité, le volume et la nature de l'activité hospitalière. L'un des efforts les plus importants et des plus novateurs pour médicaliser la description des clientèles hospitalières a été conduit aux Etats-Unis par l'équipe de R. B. Fetter (Université de Yale): il s'agit des «Diagnosis Related Groups» (DRG), développés à l'origine pour évaluer la production hospitalière.

Actuellement en cours d'évaluation, les DRG commencent à être utilisés dans la plupart des pays européens. Le but du présent numéro est de fournji un éclairage sur les récents développements ainsi que sur les perspectives d'utilisation de ces DRG en Europe occidentale. L'état d'avancement des différents projets nationaux ou régionaux est décrit dans un premier article qui indique également quelques pistes pour une harmonisation de L'Europe des DRG.

Quelles sont les raisons du succès des DRG? D'une part, les DRG utilisent des données statistiques disponibles de routine dans les hôpitaux qui font l'objet d'une centralisation à l'échelon national: ils ne nécessitent donc pas la collecte de données supplémentaires. D'autre part, le nombre restreint de groupes les rend particulièrement attrayants, puisque moins de 500 DRG suffisent pour regrouper l'ensemble des patients hospitalisés. Toutefois, ces deux conditions - informations disponibles de routine et nombre restreint de groupes - sont insuffisantes pour rendre les DRG performants. Ceux-ci doivent en plus être homogènes tant du point de vue clinique (les groupes doivent être médicalement interprétables) que du point de vue des coûts (durées de séjour et consommation des ressources semblables).

Ces aspects d'homogénéité sont largement discutés dans les études suisse (Résultats de l'étude intercantonale Casemix) et belge (Perspectives d'utilisation des $D R G$ en Belgique) qui montrent que, bien que les DRG aient été développés aux Etats-Unis, ils sont utilisables dans ces deux pays. Les stratégies d'implantation des DRG sont cependant différentes. Pour l'étude suisse, il paraît prioritaire de développer les applications de gestion des hôpitaux (calculs de coûts, comparaisons standardisées des durées de séjour, planification des lits hospitaliers) avant d'envisager un financement fondé, partiellement, sur les DRG. Les auteurs partent du principe que la qualité et la fiabilité des données médicales et des coûts seront meilleures si le mode de financement n'est pas la seule incitation à la saisie de ces informations. Il sera intéressant de voir si la gestion hospitalière de ce pays saura intégrer rapidement les DRG sans cette incitation financière directe. Le Ministère belge de la santé publique compte, au contraire, utiliser rapidement le vecteur des DRG comme critère de répartition des budgets hospitaliers. En vue de maîtriser les difficultés d'application, l'équipe belge entend développer des contrôles de la qualité du codage et améliorer le pouvoir prédictif des DRG sur les coûts en recourant à des informations supplémentaires telles que le nombre de systèmes physiologiques atteints, le type d'admission, les prestations de réanimation, etc.

Si l'introduction, en 1983, du financement prospectif par DRG pour les hôpitaux américains a rendu les DRG célèbres, elle n'a probablement pas facilité l'implantation des DRG dans les pays européens. En finançant les séjours hospitaliers plutôt que les journées d'hospitalisation ou les prestations médico-techniques, on incite les hôpitaux à limiter leurs coûts. Toutefois, l'expérience américaine a montré que le financement prospectif par DRG n'est pas dénué d'effets pervers, ce qui explique les fortes réticences observées en Europe face à ce mode de financement. Pour résoudre ces propositions antithétiques, l'article sur le financement des hopitaux et l'information sur les clientèles hospitalières propose quelques règles intéressantes qui devraient permettre de trouver une voie originale pour concilier les intérêts de tous les acteurs concernés.

La production hospitalière ne se laisse que difficilement réduire à 500 DRG environ: une importante variation résiduelle subsiste à l'intérieur de ces DRG. A l'extrême, chaque patient pourrait former un groupe à lui seul: on aurait ainsi des groupes parfaitement homogènes, mais pour lesquels aucune interprétation économique ne pourrait être faite. La validité du procédé descriptif croît donc avec le nombre de catégories (parce que l'homogénéité des groupes augmente), mais le maniement de nombreux groupes devient rapidement impraticable, notamment parce que de nombreuses catégories ne comportent plus qu'un nombre infime de séjours. Les DRG sont-ils trop réducteurs? C'est en tout cas l'avis des auteurs de l'article sur la 
Médicalisation de la gestion hospitalière aux Hôpitaux de l'Assistance publique de Paris qui dénoncent avec virulence la «vision monofactorielle» des DRG. Ils proposent de mieux tenir compte de la complexité des cas, des circonstances de l'hospitalisation, de l'évolution de la maladie et du degré de certitude des diagnostics.

«Les exigences fondamentales prealables à toute création d'une forme intelligible sont la logique et la cohérence», écrivait le compositeur Arnold Schoenberg. Les DRG n'échappent pas à cette règle: la logique et la cohérence clinique des DRG sont essentielles pour rencontrer l'adhésion du corps médical. Dans ce but, et suite aux nombreuses critiques adressées aux DRG, l'équipe de R. B. Fetter a développé de nouvelles versions (The Evolution of DRGs and Clinical Information Systems). Une prise en considération plus differenciée des diagnostics secondaires et de la sévérité a été introduite, une version pédiatrique des DRG a été développée, des programmes de contrôle de la qualité du codage sont maintenant proposés. Des indicateurs cliniques ont également été mis sur pied pour faciliter les contrôles de qualité dans les hôpitaux.
Les indicateurs de qualité se heurtent souvent à une difficulté majeure: comment mesurer l'efficacité d'un traitement en se limitant au seul séjour hospitalier? Des indicateurs tels que les taux de réadmissions ou de mortalité ajustés par la structure des clientèles hospitalières pourraient être développés, à condition de recueillir quelques informations supplémentaires permettant de faire le lien entre les statistiques de morbidité hospitalière et celles de mortalité (Data requirement for a continuous monitoring of the quality of care using $D R G$ ).

Les recommandations concernant l'utilisation des statistiques hospitalières (dernier article) émanent de l'étude Casemix qui vient de se terminer en Suisse. Bien que ces recommandations s'adressent plus particulièrement à la situation helvétique, une part importante d'entre elles restent pertinentes pour la plupart des pays. Les applications retenues dans ces différents pays n'auront pas toutes les mêmes priorités, mais partout, les DRG auront pour fonction première de faciliter le rapprochement de professionnels de formations et de sensibilités différentes.

Yves Eggli, Lausanne

\section{Editorial}

\section{What Future for Diagnosis Related Groups?}

While important progress have been realized in public health and clinical medicine since the Second World War, the management of hospitals has evolved comparatively little during the same period. Decision making processes remained the same, in spite of deep mutations in hospital structures and activities. For about twenty years, researchers tried to develop descriptive methods enabling them to grasp the complex nature of hospital activity. An important and inventive effort to medicalize the description of the hospital Casemix has been lead in the United States by R. B. Fetter's team (University of Yale): the Diagnosis Related Groups (DRGs), originally developed to assess hospital production.

DRGs are now being evaluated and are beginning to be used in most European countries. This issue gives an insight into the recent developments as well as the perspectives for use of DRGs in Western Europe. The progress of different national or regional DRG experiences is described in the first article, which pre- sents possible ways of harmonizing the use of DRGs in Europe ("L'Europe des DRG").

What are the reasons for the success of DRGs? On the one hand, DRGs use available, centralized routine hospital statistics. No additional information is needed. On the other hand, the limited number of groups (less than 500 DRGs are enough to group the whole set of in-patients) make them particularly attractive. These two conditions-available routine information and a limited number of groups-are not sufficient to make DRGs useful. They must also be homogeneous in terms of medical meaningfulness and of costs (similar length of stay and resource consumption).

These homogeneity questions are widely discussed in the Swiss and Belgian studies ("Principaux résultats de l'étude suisse sur les DRG" and "Perspectives d'utilisation des DRG en Belgique"), which show that although DRGs have been developed in the United States, they can be used in both countries. Perspectives for DRG use are different, however. For the Swiss study, the 